\title{
Prognostic and therapeutic role of HER2 expression in micropapillary carcinoma of the bladder (Review)
}

\author{
FRANCESCA SANGUEDOLCE ${ }^{1}$, DAVIDE RUSSO ${ }^{1}$, VITO MANCINI ${ }^{2}$, OSCAR SELVAGGIO $^{2}$, \\ BEPPE CALO $^{2}$, GIUSEPPE CARRIERI ${ }^{2}$ and LUIGI CORMIO ${ }^{2}$
}

\author{
Departments of ${ }^{1}$ Pathology, and ${ }^{2}$ Urology and Renal Transplantation, University Hospital, I-71121 Foggia, Italy
}

Received June 14, 2018; Accepted November 22, 2018

DOI: $10.3892 / \mathrm{mco} .2018 .1786$

\begin{abstract}
Micropapillary carcinoma of the bladder (MPBC) is a variant type of infiltrating urothelial carcinoma, which portends a poor biological behavior in terms of disease stage at first diagnosis and clinical outcome; its peculiar morphology raises issues concerning the ability of tumor detection by imaging techniques and proper biopsy procedure, and the appropriate treatment for non-muscle infiltrating and muscle-infiltrating MPBC remains a matter of debate. On the basis of its established prognostic and therapeutic role in breast and gastro-esophageal cancer in the first instance, the human epidermal growth factor receptor-2 (HER2) has been investigated in selected case series of MPBC over the last 10 years. The aim of the present review was to summarize the existing evidence on HER2 status in MPBC, and to discuss its present and future utility in risk assessment and treatment choice of this uncommon, yet aggressive, disease.
\end{abstract}

\section{Contents}

1. Introduction

2. $\mathrm{MPBC}$

3. HER2

4. HER2 in MPBC

5. Conclusion

\section{Introduction}

The micropapillary variant of carcinoma (MPC) has been reported in several organs, including bladder, lung, breast, salivary gland, gastrointestinal tract and ovary (1-6). This variant exhibits a peculiar morphology; depending on whether tumor cells are superficial or invasive, they may aggregate

Correspondence to: Dr Francesca Sanguedolce, Department of Pathology, University Hospital, 1 Viale Pinto, I-71121 Foggia, Italy

E-mail: fradolce@hotmail.com

Key words: micropapillary variant, bladder cancer, human epidermal growth factor receptor-2, immunohistochemistry, in situ hybridization as slender delicate papillary projections or small compact infiltrating nests of four or five cells lacking central vascular cores, floating within clear spaces similar to lymphatic channels due to the production of peritumoral stromal retraction artifacts (7-11). Tumor cells usually feature peripherally located high-grade nuclei and cytoplasmic vacuoles $(12,13)$, as well as an inverted cellular polarity to the external surface of neoplastic clusters which, according to certain studies, may result in the basal surface acquiring apical secretory properties that promote tumor invasion, and a highly aggressive clinical outcome [(3), reviewed in (14)]. In fact, MPC typically leads to a poor prognosis with a greater risk of nodal metastases in comparison with corresponding conventional carcinoma $(1-5,8,15,16)$. It has been postulated that, on the basis of its molecular profile, MPC represents a distinct entity $(17,18)$.

The morphological similarities between MPC from different organs as well as the high frequency of metastases accounts for the requirement to differentiate between primary and secondary MPC of the bladder; therefore, a proper immunohistochemical panel as well as disclosing a simultaneous component of conventional urothelial carcinoma may support a correct diagnosis (19).

The aim of the present review was to summarize current knowledge on human epidermal growth factor receptor-2 (HER2) expression in micropapillary bladder carcinoma (MPBC) because this marker is considered to be a potential prognostic and therapeutic marker in this tumor.

\section{MPBC}

Epidemiology. MPBC was first described in 1994 as a rare variant of urothelial bladder cancer (UBC) resembling papillary serous carcinoma of the ovary (1); its incidence has been reported as $0.6-8.2 \%$ of all bladder tumors [(1), reviewed in $(10)$; $(11,15)$, reviewed in $(20-22)]$, with the majority of recent studies reporting the highest values, possibly due to more accurate diagnosis, notwithstanding a suboptimal inter-observer reproducibility (9).

This tumor predominantly affects men, with a male-to-female ratio of 5-10:1, which is higher than conventional UBC $[(1,9,22,12)$, reviewed in (10)]. The age range at presentation is wide (between 22 and 81 years; mean, 67.6 years), and the most common reported symptoms are 
hematuria, dysuria, urgency, frequency, urinary obstruction, urinary tract infection, weight loss and, as for upper tract tumors, flank pain [(1,21-26), reviewed in (10)].

Cytology. Urine cytological smears feature papillary/spheroid aggregates of tumor cells with high nuclear grade together with rare single cells in a clear background, due to the endophytic rather than exophytic nature of the tumor (27).

Macroscopy. Gross appearance of MPBC is varied, since it can range from papillary and polypoid to ulcerative and infiltrating, and can differ in size from microscopic to a huge mass (22).

Microscopy. MPBC is associated with conventional UBC and carcinoma in situ (CIS) in 85 and $65 \%$ of patients, respectively $(15,28)$, and coexistence has been reported with other variants of UBC as well as other histotypes $(15,24,26)$; sometimes it has been described as infiltrating the lamina propria under areas of normal overlying mucosa (28). Although a correct diagnosis of MPBC is of pivotal importance, it may be difficult to distinguish such a variant from typical invasive UBC with noticeable retraction artifacts, as identified by Sangoi et al (9) in an assessment of the inter-observer agreement among uropathologists for the diagnosis of MPBC (Fig. 1). Their observations suggest that the size and pattern of tumor cell aggregates (i.e., small multiple nests within the same lacunar space compared with large branching) may support the diagnosis of MPBC and conventional UBC, respectively.

Further categorization is required between invasive and non-invasive MPBC, since the latter may not portend a poor prognosis (29). In fact, it is now recognized that a micropapillary (MP)-like architecture may be seen in non-muscle-invasive bladder cancer (NMIBC) and CIS; therefore, if the MP component is limited to the non-invasive component, the tumor should not be defined as MPBC (9,29-36). On the other hand, mixed neoplasms (conventional BC combined with MPBC) often exhibit a poorer biological behavior as well as metastases with MP morphology only, supporting the aggressive nature of this variant $(1,12,31,37)$. Evidence exists that the higher the proportion of MPBC present, the poorer the biological behavior in terms of stage of disease and clinical outcome; a relative mortality risk of 2.4 exists when the component of MPBC is $>50 \%$ compared with those with pure conventional UBC or $<50 \%$ MPC (24). Furthermore, cases with $<10 \%$ and/or superficial MP component may be more frequently detected at an early stage (31). Therefore, despite the absence of accepted criteria for the cut-off proportion of MP component to qualify a UBC as MPBC alone, it is recommended to report the presence and the proportion of MP component in the pathology report $(37,38)$, possibly quantifying it in percentage terms.

Immunohistochemistry and molecular biology. MPBC features an immunohistochemical profile similar as the one described in conventional UBC, exhibiting cytokeratin (CK)7 expression in all cases, as well as reactivity for uroplakin III, CK34 $3 \mathrm{E} 12$, CK20, p63, thrombomodulin and high-molecular-weight CK, with decreasing frequency $(19,31)$. Furthermore, MPBC is negative for estrogen receptor, mammaglobin, paired box gene 8, thyroid transcription factor 1 and Wilms' tumor protein 1, which allows the differentiation of a primary bladder cancer from lung, breast and ovary cancer, but not from pancreatic and salivary gland cancer $(1,19)$. Eventually, a correct diagnosis of secondary MPC requires proper clinical and radiological correlation.

With the aim of discriminating between MPBC and conventional UBC, molecules such as mucin 1, cancer antigen 125, HER2/neu and Krebs von den Lungen- 6 have been studied as putative diagnostic markers for MPBC, yielding conflicting results $(7,9,15,28,29,31-35,39-45)$.

In a recent gene expression profile study, downregulation of microRNA-296 and activation of chromatin-remodeling complex RuvB-like 1 that may be associated with epidermal growth factor receptor (EGFR) have been reported as prominent features of MPBC (46). Furthermore, according to recent molecular data, most MPBC, even as part of conventional UBC, refers to the luminal molecular subtype $(26,46)$, consistent with the MP variant of breast cancer (17).

Diagnostic methods. Since MPBC may not form discrete lesions unlike most conventional UBC, computed tomography or other imaging studies may fail to detect such diffuse neoplasms $(28,47)$.

When MPBC grows under normal mucosa, routine follow-up cystoscopy and urine cytology are unable to detect neoplastic cells (28), and cold cup biopsy may miss an MPBC invading the muscle layer under the benign surface epithelium; thus, deep biopsies are recommended $(1,47,48)$.

Clinical outcome and treatment. In the bladder as well, MPC is considered to portend an aggressive clinical course, with most patients presenting at an advanced stage with muscle-invasive or metastatic disease $(1,15)$.

Putative mechanisms accounting for the dismal prognosis of such disease are: i) A high level of inherent chromosomal or genomic instability, with excess DNA contents [DNA index (the ratio between the DNA content of a tumor cell and that of a normal diploid cell), 1.75] compared with conventional UBC, which is further increased in metastatic MPBC $(1,37)$; and ii) an increased expression of the markers of poor prognosis p53, Mindbomb E3 ubiquitin protein ligase 1, Aurora-A and survivin (49-52). In a large case series of MPBC, $>50 \%$ were at least clinical tumor stage 2 at first diagnosis [reviewed in (10)], and subsequent pathological upstaging may occur in $<75 \%$ of patients with NMIBC. Other studies identified a lower proportion of patients at advanced stage at cystectomy (53), and even no differences in outcome following radical cystectomy between MPBC and conventional UBC when matched for stage and other clinicopathological variables (29).

Lymphovascular invasion, which is a strong marker of adverse prognosis, is present in $<75 \%$ cases at diagnosis, and occult nodal disease may be present in $<38 \%$ patients [reviewed in (10)]. In case series of MPBC, 5- and 10-year survival rates of 25-74 and $24-54 \%$ have been reported, due either to its high growth rate or to its inherent biologically aggressive behavior [(47,54), reviewed in (10)]. As a consequence: i) Even in the absence of evidence of muscularis propria invasion in a biopsy, muscle invasion is often assumed (55) and/or additional tissue sampling and restaging should be considered; and 

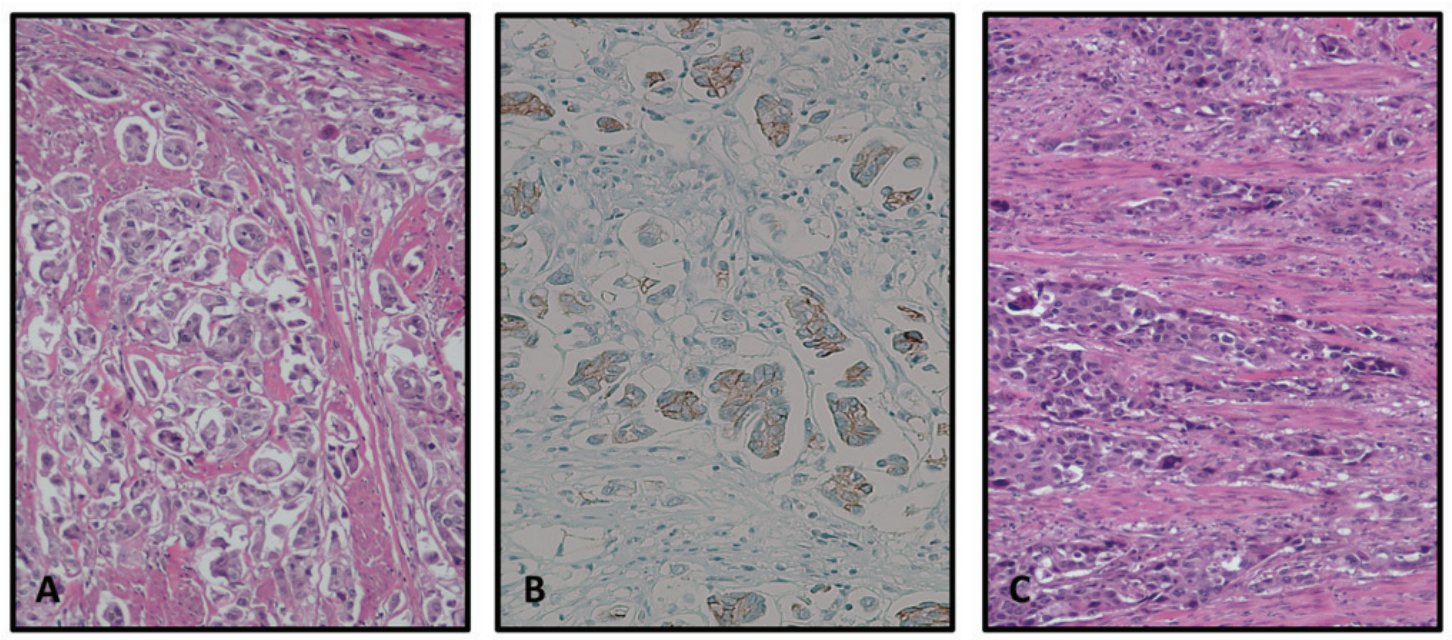

Figure 1. (A) Hematoxylin and eosin staining of MPBC revealing small multiple nests within the same lacunar space. (B) Conventional urothelial bladder cancer featuring wide anastomosing cords of pleomorphic cells. (C) Membrane staining of MPBC tumor cells for HER2. MPBC, membrane staining of micropapillary carcinoma; HER2, human epidermal growth factor receptor-2.

ii) radical cystectomy has been suggested as a first-line therapy in place of neoadjuvant chemotherapy in muscle-invasive disease and conservative therapy with intravesical Bacillus Calmette-Guérin in NMIBC [(28,54,55), reviewed in (10)]; the latter has been identified to be critically ineffective in patients with MPBC $[(15,54,56)$, reviewed in (10)]. For patients submitted to early cystectomy for NMIBC, 10-year survival rates of $72 \%$ have been reported, compared with $0 \%$ following conventional therapies [reviewed in (10)], although subsequent studies yielded conflicting results. Meeks et al (53) identified no residual disease at cystectomy in $45 \%$ of the patients who received neoadjuvant chemotherapy (four cycles of gemcitabine and cisplatin in the majority of cases), in keeping with a Phase III trial which documented an improved response to neoadjuvant chemotherapy in tumors with mixed histology compared with in pure UBC (57). Other studies failed to demonstrate any significant difference in outcomes with the addition of neoadjuvant chemotherapy in patients with muscle-invasive MPBC undergoing radical cystectomy $(32,58)$.

Recently, Fernández et al (59) reported that neoadjuvant chemotherapy appears to confer benefit to patients with MPBC without tumor-associated hydronephrosis, whereas patients with clinical tumor stage 1 disease may undergo standard surgical treatment.

\section{HER2}

Background. HER2 (ERBB2; HER2/neu) is a type I transmembrane $185 \mathrm{kDa}$ tyrosine kinase receptor whose encoding gene is on chromosome 17q21 $(60,61)$. HER2 is usually present as an inactive monomer on the cell membrane of various cell types undergoing homo- or heterodimerization with other EGFR family members (62) via activation by corresponding ligands in response to extracellular signals. HER2 is normally responsible for regulating cell proliferation and survival, inhibiting apoptosis, increasing angiogenesis and decreasing cell-cell adhesion by the activation of various cell signaling pathways (63-65), which are important factors in oncogenesis and tumor progression (65-67). Thus, HER2 overexpression has been identified in several tumor types, including bladder, breast, ovarian, salivary gland, endometrial, pancreatic and non-small cell lung cancer $(65,66,68)$. HER2 protein overexpression was initially and has been most extensively researched in breast cancer, in which it occurs in almost $20 \%$ of primary invasive carcinomas (69), and is associated with poor prognosis with decreased disease-free and overall survival $(65,69)$; similar evidence has been reported for bladder cancer (70).

Therapeutic target. At present, HER2-targeted therapies are established clinical routines for HER2-overexpressing/amplified carcinomas of the breast $(71,72)$ and stomach (73) via the application of the anti-HER2 humanized monoclonal antibody trastuzumab (72). HER2-targeted therapy in combination with standard chemotherapy has resulted in a significantly increased survival rate in patients with HER2 amplification in breast and gastro-esophageal cancer $(73,74)$.

HER2 in bladder cancer. There are conflicting data in the literature regarding HER2 status in BC samples. Previous investigation has identified a highly variable frequency of gene amplification ranging between 0 and 59\% of cases (66,75-80), with HER2 protein expression reported in between 31 and $65.5 \%$ of samples $(75,81,82)$. Nevertheless, according to the majority of studies, HER2 protein expression seems to be correlated with tumor stage, tumor grade and outcome (82-89); in fact, the reason for this variability of results has been attributed to high heterogeneity of case series, which include different grades and histological variants of BC $(34,35,90-94)$. A previous study identified that the 5 -year disease-free survival rate decreased from $48.5 \%$ in HER2-negative patients to $9.7 \%$ in those who were HER2-positive (86). Skagias et al (85), also identified that HER 2 expression was correlated with decreased disease-specific survival $(\mathrm{P}=0.002)$ and overall survival rates $(\mathrm{P}=0.025)$.

Previous studies have highlighted the apparent lack of a marked association between HER 2 protein expression and gene amplification in BC (81), with the latter being characterized by extreme heterogeneity within the same tumor (95). In addition, 


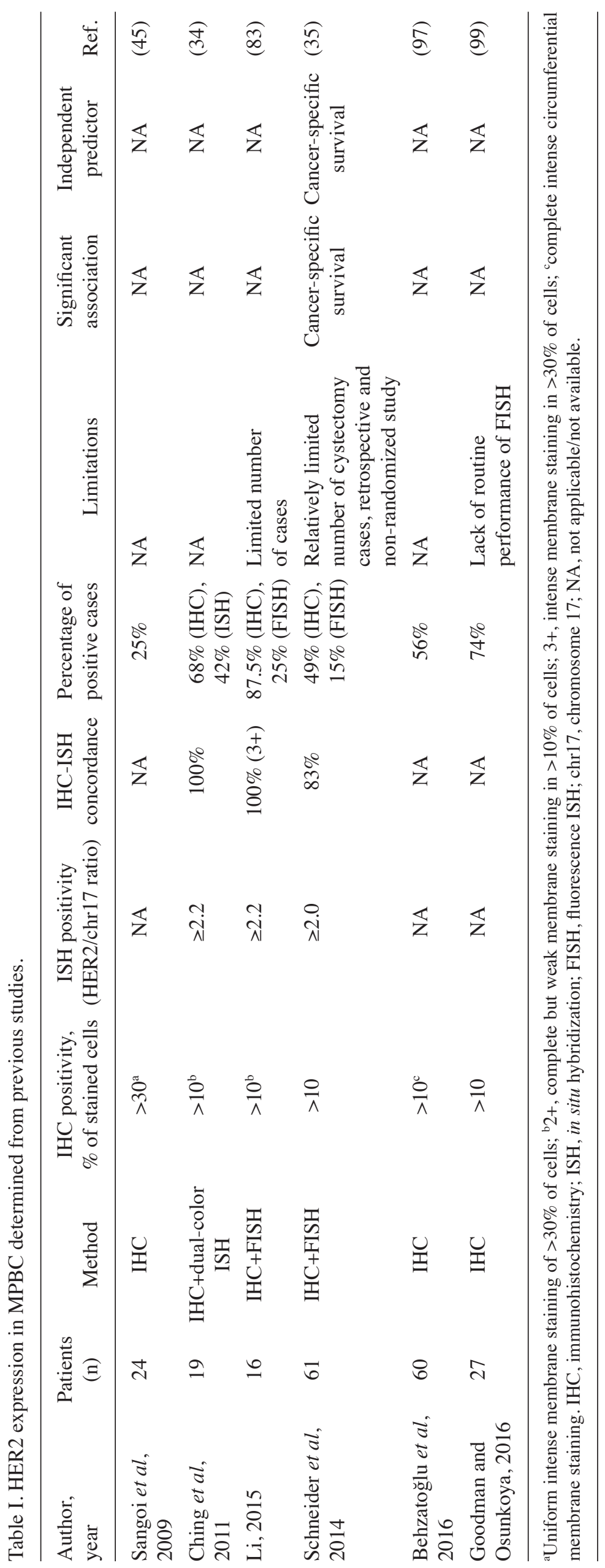


it has been considered that gene amplification may not be the mechanism underlying protein overexpression (96).

\section{HER2 in MPBC}

As MPC exhibits a morphology and behavior distinct from that of conventional UBC, it has been hypothesized that such differences could be an effect of differences in growth-promoting factors such as HER2 (34).

Tschui et al (61), described an aggressive HER2-amplified subtype of UBC with specific features, comprising frequent $(77 \%)$ MP tumor growth and high morphological heterogeneity, as well as brisk tumor-associated chronic inflammation.

The most representative studies investigating HER2 status in MPBC are summarized in Table I.

Immunohistochemistry. Attempts have been made to investigate HER 2 as a marker in the differential diagnosis between MPBC and UBC. In 2004, Zhang et al (43) identified overexpression of HER2 in 10 MPBC vs. 59 conventional UBC cases, reporting a sensitivity and specificity of 100 and 57\%, respectively. Conversely, Sangoi et al (45) reported specificity as high as $92 \%$ for HER 2 positivity by immunohistochemistry (IHC) (comprising 2+ and 3+ staining) in MPBC compared with conventional UBC with retraction artifacts; furthermore, in the same study, a very low sensitivity (25\%) was achieved and statistical significance was lacking (45). In keeping with such data, HER 2 protein overexpression has been identified in a significantly higher proportion of cases of MPBC compared with UBC (56-87.5 vs. 31.25-50\%, respectively) $(34,92,97)$, with higher homogeneity (97), as well as in invasive conventional or variant histology UBC in combination with MPBC $(97,98)$. In a recent series of MPBC only, the frequency of HER2 positivity was as high as $74 \%$ (99). The most recent studies have failed to identify a statistically significant association between HER2 expression and MP differentiation $(100,101)$.

Such conflicting results may arise for several reasons, including fixation issues, heterogeneity in stage and grade, use of different antibodies and use of tissue sections rather than tissue microarray $(35,92,97)$. A further limitation is the heterogeneity of cut-off used to determine HER2 positivity. Unlike for breast and gastro-esophageal cancer, established guidelines for HER2 assessment in UBC do not exist, and the literature regarding HER2 expression in UBC often defines overexpression as $2+$ and $3+$ staining $(66,70,72,81,102,103)$, whereas current breast and gastro-esophageal guidelines consider positive $3+$ cases only.

HER 2 overexpression has been advocated as an early event in urothelial tumorigenesis and only rarely in subsequent tumor development, also because of the occurrence of HER2-positive CIS in cases of infiltrating HER2-overexpressing UBC (61), as well as its higher frequency in less advanced disease (99).

In situ hybridization (ISH). In certain types of cancer, such as breast, ovarian, and gastric cancer, HER2 gene amplification assessed by ISH and protein expression are well-correlated $(69,104)$, with HER2 gene amplification identified in $>90 \%$ of patients with breast cancer demonstrating HER2 protein overexpression (65). Studies have revealed that MPBC exhibits HER2 amplification in $<42 \%$ cases $(34,35,61,92)$, in comparison with a much lower frequency of $<14 \%$ in $\operatorname{UBC}(35,75,105)$. As a prognostic factor, HER2 amplification (but not overexpression) exhibits a significant association with a significant increase in cancer-specific mortality (35), whereas another study failed to identify such an association in a smaller case series (34), possibly due to differences in patient selection criteria and methods, as well as the proportion of the MP component in the tumor and on the sample selected (99). On the basis of such results, it has been suggested that HER2 status may be a tool for pre-surgical risk stratification of these patients.

Previous studies identified a significant association between protein expression and gene amplification in MPBC, supporting the hypothesis that IHC may also provide reliable results in this setting $(34,35,92)$. Schneider et al $(35)$, highlighted that, despite a positive predictive value as high as $83 \%$, IHC exhibited a very low negative predictive value (27\%); it is well-known that other mechanisms may account for HER2 overexpression, including transcriptional or post-transcriptional dysregulation (95). On the other hand, those cases showing HER2 negativity by IHC and simultaneous HER2 amplification have been attributed to putative fixation artifacts (61).

Molecular biology. Genomic analyses identified that MPBC carries a significant high frequency of unique activating mutations in the extracellular domain of HER2 in comparison with conventional BC (34 vs 5\%, respectively) $(13,106)$. The point-mutated MPBC are not amplified nor overexpress HER2, thus being de facto undetectable using standard techniques (ISH and IHC).

In their series, Tschui et al (61) detected a novel D769N mutation in one case in association with HER2 amplification. As a marker of potential chromosomal and genomic instability, aneusomy 17 has been detected in $>50 \%$ cases of MPBC in a series (34).

Therapeutic target. Although, to the best of our knowledge, there have not been any studies evaluating HER2-targeted therapy in MPBC, several trials have investigated its role in conventional BC (as aforementioned). Unfortunately, these studies have had limited success, possibly because of the low rates of gene amplification in this population. In a Phase II study of lapatinib, a dual tyrosine kinase inhibitor of EGFR and HER2, only $1.7 \%$ of patients with locally advanced or metastatic BC exhibited an objective response $(75,107)$. A separate Phase II trial that combined trastuzumab (a monoclonal antibody against HER2) with carboplatin, paclitaxel and gemcitabine identified a complete response in 5/44 (11.4\%) HER2-positive patients and a partial response in 26/44 (59.1\%) patients (defined as a $\geq 50 \%$ decrease in the size of the lesion) (80).

In the breast, MP histology was described as a predictor of lower response to standard adjuvant anti-HER2 targeted therapy (trastuzumab) and chemotherapy (108). Although a number of these studies used HER2 protein expression as a marker for potential therapeutic response, the lack of correlation between protein levels and gene amplification, and the low number of conventional urothelial carcinomas that exhibit HER 2 gene amplification may explain these results. In contrast, the high frequency of gene amplification in MPBC (34) makes 
this variant a candidate for targeted treatment with anti-HER2 antibody.

\section{Conclusion}

Over the last decade, studies focusing on HER2 assessment in MPBC have identified frequent overexpression of this marker, suggesting that it might aid in patient risk stratification and treatment selection in this aggressive type of BC. With this in mind, standardization of techniques and development of proper assessment guidelines are required, as well as larger multi-institutional studies in order to confirm such results. Furthermore, prospective clinical trials are required to examine the application of targeted therapy in this aggressive disease.

\section{Acknowledgements}

Not applicable.

\section{Funding}

No funding was received.

\section{Availability of data and materials}

Not applicable.

\section{Authors' contributions}

FS, GC and LC were responsible for the conception of the review, acquisition, analysis and interpretation of data for the review, drafting the review and revising it critically for important intellectual content. DR, BC and VM were responsible for the analysis and interpretation of data for the review and drafting the review. OS was responsible for the analysis and interpretation of data for the review, drafting the review, creating the table and revising it critically for important intellectual content. All authors gave final approval of the version to be published.

\section{Ethics approval and consent to participate}

Not applicable.

\section{Patient consent for publication}

Not applicable.

\section{Competing interests}

The authors declare that they have no competing interests.

\section{References}

1. Amin MB, Ro JY, el-Sharkawy T, Lee KM, Troncoso P, Silva EG, Ordóñez NG and Ayala AG: Micropapillary variant of transitional cell carcinoma of the urinary bladder. Histologic pattern resembling ovarian papillary serous carcinoma. Am J Surg Pathol 18: 1224-1232, 1994.

2. Amin MB, Tamboli P, Merchant SH, Ordóñez NG, Ro J, Ayala AG and Ro JY: Micropapillary component in lung adenocarcinoma: A distinctive histologic feature with possible prognostic significance. Am J Surg Pathol 26: 358-364, 2002.
3. Luna-Moré S, Gonzalez B, Acedo C, Rodrigo I and Luna C: Invasive micropapillary carcinoma of the breast. A new special type of invasive mammary carcinoma. Pathol Res Pract 190: 668-674, 1994

4. Nagao T, Gaffey TA, Visscher DW, Kay PA, Minato H, Serizawa H and Lewis JE: Invasive micropapillary salivary duct carcinoma: A distinct histologic variant with biologic significance. Am J Surg Pathol 28: 319-326, 2004.

5. Sakamoto K, Watanabe M, De La Cruz C, Honda H, Ise H, Mitsui K, Namiki K, Mikami Y, Moriya T and Sasano H: Primary invasive micropapillary carcinoma of the colon. Histopathology 47: 479-484, 2005.

6. Smith Sehdev AE, Sehdev PS and Kurman RJ: Noninvasive and invasive micropapillary (low-grade) serous carcinoma of the ovary: A clinicopathologic analysis of 135 cases. Am J Surg Pathol 27: 725-736, 2003.

7. Nassar H, Pansare V, Zhang H, Che M, Sakr W, Ali-Fehmi R, Grignon D, Sarkar F, Cheng J and Adsay V: Pathogenesis of invasive micropapillary carcinoma: Role of MUC1 glycoprotein. Mod Pathol 17: 1045-1050, 2004.

8. Nassar H: Carcinomas with micropapillary morphology: Clinical significance and current concepts. Adv Anat Pathol 11: 297-303, 2004.

9. Sangoi AR, Beck AH, Amin MB, Cheng L, Epstein JI, Hansel DE, Iczkowski KA, Lopez-Beltran A, Oliva E, Paner GP, et al: Interobserver reproducibility in the diagnosis of invasive micropapillary carcinoma of the urinary tract among urologic pathologists. Am J Surg Pathol 34: 1367-1376, 2010.

10. Kamat AM, Dinney CP, Gee JR, Grossman HB, Siefker-Radtke AO, Tamboli P, Detry MA, Robinson TL and Pisters LL: Micropapillary bladder cancer: A review of the University of Texas M. D. Anderson Cancer Center experience with 100 consecutive patients. Cancer 110: 62-67, 2007.

11. López JI, Elorriaga K, Imaz I and Bilbao FJ: Micropapillary transitional cell carcinoma of the urinary bladder. Histopathology 34 : 561-562, 1999.

12. Compérat E, Roupret M, Yaxley J, Reynolds J, Varinot J, Ouzaïd I, Cussenot $\mathrm{O}$ and Samaratunga $\mathrm{H}$ : Micropapillary urothelial carcinoma of the urinary bladder: A clinicopathological analysis of 72 cases. Pathology 42: 650-654, 2010.

13. Ross JS, Wang K, Gay LM, Al-Rohil RN, Nazeer T, Sheehan CE, Jennings TA, Otto GA, Donahue A, He J, et al: A high frequency of activating extracellular domain ERBB2 (HER2) mutation in micropapillary urothelial carcinoma. Clin Cancer Res 20: 68-75, 2014.

14. Perepletchikov AM and Parwani AV: Micropapillary urothelial carcinoma: Clinico-pathologic review. Pathol Res Pract 205: 807-810, 2009.

15. Johansson SL, Borghede G and Holmäng S: Micropapillary bladder carcinoma: A clinicopathological study of 20 cases. J Urol 161: 1798-1802, 1999.

16. Paterakos M, Watkin WG, Edgerton SM, Moore DH II and Thor AD: Invasive micropapillary carcinoma of the breast: A prognostic study. Hum Pathol 30: 1459-1463, 1999.

17. Marchiò C, Iravani M, Natrajan R, Lambros MB, Savage K, Tamber N, Fenwick K, Mackay A, Senetta R, Di Palma S, et al: Genomic and immunophenotypical characterization of pure micropapillary carcinomas of the breast. J Pathol 215: 398-410, 2008.

18. Weigelt B, Horlings HM, Kreike B, Hayes MM, Hauptmann M, Wessels LF, de Jong D, Van de Vijver MJ, Van't Veer LJ and Peterse JL: Refinement of breast cancer classification by molecular characterization of histological special types. J Pathol 216: 141-150, 2008.

19. Lotan TL, Ye H, Melamed J, Wu XR, Shih IeM and Epstein JI: Immunohistochemical panel to identify the primary site of invasive micropapillary carcinoma. Am J Surg Pathol 33: 1037-1041, 2009.

20. Trabelsi A, Stita W, Soumaya R, Mestiri S, Jaidene M, Mokni M and Korbi S: Micropapillary carcinoma of the urinary bladder: A case report and review of the literature. Can Urol Assoc J 2: 540-542, 2008.

21. Alkibay T, Sözen S, Gürocak S, Işik Gönül I, Poyraz A and Ure I: Micropapillary pattern in urothelial carcinoma: A clinicopathological analysis. Urol Int 83: 300-305, 2009.

22. Watts KE and Hansel DE: Emerging concepts in micropapillary urothelial carcinoma. Adv Anat Pathol 17: 182-186, 2010.

23. Samaratunga $\mathrm{H}$ and Delahunt B: Recently described and unusual variants of urothelial carcinoma of the urinary bladder. Pathology 44: 407-418, 2012. 
24. Alvarado-Cabrero I, Sierra-Santiesteban FI, Mantilla-Morales A and Hernández-Hernandez DM: Micropapillary carcinoma of the urothelial tract. A clinicopathologic study of 38 cases. Ann Diagn Pathol 9: 1-5, 2005.

25. Heudel P, El Karak F, Ismaili N, Droz JP and Flechon A: Micropapillary bladder cancer: A review of Léon Bérard Cancer Center experience. BMC Urol 9: 5, 2009.

26. Lopez-Beltran A, Cheng L, Raspollini MR, Canas-Marques R Scarpelli M, Cimadamore A, Gasparrini S and Montironi R: Variants of bladder cancer: The pathologist's point of view. Eur Urol Suppl 16: 210-222, 2017.

27. Sakuma T, Furuta M, Mimura A, Tanigawa N, Takamizu R and Kawano K: Urine cytology of micropapillary carcinoma of the urinary bladder. Diagn Cytopathol 39: 852-856, 2011.

28. Maranchie JK, Bouyounes BT, Zhang PL, O'Donnell MA Summerhayes IC and DeWolf WC: Clinical and pathological characteristics of micropapillary transitional cell carcinoma: A highly aggressive variant. J Urol 163: 748-751, 2000.

29. Amin A and Epstein JI: Noninvasive micropapillary urothelial carcinoma: A clinicopathologic study of 18 cases. Hum Pathol 43 2124-2128, 2012.

30. Moch H, Humphrey PA, Ulbright TM and Reuter V (eds): WHO Classification of Tumors of the Urinary System and Male Genital Organs. Vol 8. 4th edition. IARC Press, Lyon, France, 2016.

31. Samaratunga $H$ and Khoo K: Micropapillary variant of urothelial carcinoma of the urinary bladder; a clinicopathological and immunohistochemical study. Histopathology 45: 55-64, 2004.

32. Willis DL, Fernandez MI, Dickstein RJ, Parikh S, Shah JB, Pisters LL, Guo CC, Henderson S, Czerniak BA, Grossman HB, et al: Clinical outcomes of cT1 micropapillary bladder cancer. J Urol 193: 1129-1134, 2015.

33. Wang JK, Boorjian SA, Cheville JC, Kim SP, Tarrell RF, Thapa P and Frank I: Outcomes following radical cystectomy for micropapillary bladder cancer versus pure urothelial carcinoma: A matched cohort analysis. World J Urol 30: 801-806, 2012

34. Ching CB, Amin MB, Tubbs RR, Elson P, Platt E, Dreicer R, Fergany A and Hansel DE: HER2 gene amplification occurs frequently in the micropapillary variant of urothelial carcinoma: Analysis by dual-color in situ hybridization. Mod Pathol 24: 1111-1119, 2011.

35. Schneider SA, Sukov WR, Frank I, Boorjian SA, Costello BA, Tarrell RF, Thapa P, Houston Thompson R, Tollefson MK, Jeffrey Karnes R, et al: Outcome of patients with micropapillary urothelial carcinoma following radical cystectomy: ERBB2 (HER2) amplification identifies patients with poor outcome. Mod Pathol 27: 758-764, 2014

36. Patriarca $\mathrm{C}$ and Giunta $\mathrm{P}$ : Invasive micropapillary carcinoma: Beyond the borders. Am J Surg Pathol 35: 311-312, 2011.

37. Amin MB: Histological variants of urothelial carcinoma: Diagnostic, therapeutic and prognostic implications. Mod Pathol 22 (Suppl 2): S96-S118, 2009.

38. Humphrey PA: Micropapillary urothelial carcinoma of the urinary tract. J Urol 186: 1071-1072, 2011.

39. Lopez-Beltran A, Montironi R, Blanca A and Cheng L: Invasive micropapillary urothelial carcinoma of the bladder. Hum Pathol 41: 1159-1164, 2010.

40. Oh YL and Kim KR: Micropapillary variant of transitional cell carcinoma of the ureter. Pathol Int 50: 52-56, 2000.

41. Perez-Montiel D, Wakely PE, Hes O, Michal M and Suster S High-grade urothelial carcinoma of the renal pelvis: Clinicopathologic study of 108 cases with emphasis on unusual morphologic variants. Mod Pathol 19: 494-503, 2006.

42. Kuroda N, Tamura M, Ohara M, Hirouchi T, Mizuno K and Miyazaki E: Invasive micropapillary carcinoma of the urinary bladder: An immunohistochemical study of neoplastic and stromal cells. Int J Urol 13: 1015-1018, 2006.

43. Zhang HSR, Ali-Fehmi R and Bianco F: Characteristic immunohistochemical profiles and aggressive behavior of micropapillary and other histological variants and subtypes of urothelial carcinoma. Mod Pathol 17 (Suppl 1):186A(782),2014.

44. Ohtsuki Y, Kuroda N, Umeoka T, Watanabe R, Ochi K, Okada Y, Lee GH and Furihata M: KL-6 is another useful marker in assessing a micropapillary pattern in carcinomas of the breast and urinary bladder, but not the colon. Med Mol Morphol 42: $123-127,2009$

45. Sangoi AR, Higgins JP, Rouse RV, Schneider AG and McKenney JK: Immunohistochemical comparison of MUC1 CA125, and Her2Neu in invasive micropapillary carcinoma of the urinary tract and typical invasive urothelial carcinoma with retraction artifact. Mod Pathol 22: 660-667, 2009.
46. Guo CC, Dadhania V, Zhang L, Majewski T, Bondaruk J, Sykulski M, Wronowska W, Gambin A, Wang Y, Zhang S, et al: Gene expression profile of the clinically aggressive micropapillary variant of bladder cancer. Eur Urol 70: 611-620, 2016.

47. Nishizawa K, Kobayashi T, Mitsumori K, Ide Y, Watanabe J and Ogura K: Micropapillary bladder cancer. Int J Urol 12: 506-508, 2005.

48. Kwon GY and Ro JY: Micropapillary variant of urothelial carcinoma. Adv Urol 2011: 217153, 2011.

49. Compérat E, Roupret M, Conort P, Chartier-Kastler E, Bitker MO, Richard F, Capron F, Haertig A, Cussenot O and Camparo P: Aurora-A/STK-15 is differentially expressed in the micropapillary variant of bladder cancer. Urol Int 82: 312-317, 2009.

50. Sen S, Zhou H, Zhang RD, Yoon DS, Vakar-Lopez F, Ito S, Jiang F, Johnston D, Grossman HB, Ruifrok AC, et al: Amplification/overexpression of a mitotic kinase gene in human bladder cancer. J Natl Cancer Inst 94: 1320-1329, 2002.

51. Cormio L, Tolve I, Annese P, Saracino A, Zamparese R, Sanguedolce F, Bufo P, Battaglia M, Selvaggi FP and Carrieri G: Retinoblastoma protein expression predicts response to bacillus Calmette-Guérin immunotherapy in patients with T1G3 bladder cancer. Urol Oncol 28: 285-289, 2010.

52. Cormio L, Tolve I, Annese P, Saracino A, Zamparese R, Sanguedolce F, Bufo P, Battaglia M, Selvaggi FP and Carrieri G: Altered $\mathrm{p} 53$ and $\mathrm{pRb}$ expression is predictive of response to $\mathrm{BCG}$ treatment in T1G3 bladder cancer. Anticancer Res 29: 4201-4204, 2009.

53. Meeks JJ, Taylor JM, Matsushita K, Herr HW, Donat SM, Bochner BH and Dalbagni G: Pathological response to neoadjuvant chemotherapy for muscle-invasive micropapillary bladder cancer. BJU Int 111: E325-E330, 2013.

54. Kamat AM, Gee JR, Dinney CP, Grossman HB, Swanson DA, Millikan RE, Detry MA, Robinson TL and Pisters LL: The case for early cystectomy in the treatment of nonmuscle invasive micropapillary bladder carcinoma. J Urol 175: 881-885, 2006.

55. Zhai QJ, Black J, Ayala AG and Ro JY: Histologic variants of infiltrating urothelial carcinoma. Arch Pathol Lab Med 131: 1244-1256, 2007.

56. Black PC, Brown GA and Dinney CPN: The impact of variant histology on the outcome of bladder cancer treated with curative intent. Urol Oncol 27: 3-7, 2009.

57. Scosyrev E, Ely BW, Messing EM, Speights VO, Grossman HB, Wood DP, de Vere White RW, Vogelzang NJ, Trump DL, Natale RB, et al: Do mixed histological features affect survival benefit from neoadjuvant platinum-based combination chemotherapy in patients with locally advanced bladder cancer? A secondary analysis of Southwest Oncology Group-Directed Intergroup Study (S8710). BJU Int 108: 693-699, 2011.

58. Canvasser N, Weizer A, Crossley H, Dailey S, He C, Kunju LP Lee C, Hafez K, Hollenbeck B, Morgan T, Montie J and Montgomery J: Micropapillary Differentiation Versus Conventional Urothelial Carcinoma: Effects Of Neoadjuvant Chemotherapy And Cystectomy On Survival. AUA 2014 conference, abstract MP50-06.

59. Fernández MI, Williams SB, Willis DL, Slack RS, Dickstein RJ, Parikh S, Chiong E, Siefker-Radtke AO, Guo CC, Czerniak BA, et al: Clinical risk stratification in patients with surgically resectable micropapillary bladder cancer. BJU Int 119: 684-691, 2017

60. Schechter AL, Stern DF, Vaidyanathan L, Decker SJ, Drebin JA, Greene MI and Weinberg RA: The neu oncogene: An erb-B-related gene encoding a 185,000-Mr tumour antigen. Nature 312: 513-516, 1984.

61. Tschui J, Vassella E, Bandi N, Baumgartner U, Genitsch V, Rotzer D, Seiler R, Thalmann GN and Fleischmann A: Morphological and molecular characteristics of HER 2 amplified urothelial bladder cancer. Virchows Arch 466: 703-710, 2015.

62. Zwick E, Bange J and Ullrich A: Receptor tyrosine kinase signalling as a target for cancer intervention strategies. Endocr Relat Cancer 8: 161-173, 2001.

63. Yarden Y and Sliwkowski MX: Untangling the ErbB signalling network. Nat Rev Mol Cell Biol 2: 127-137, 2001.

64. Wen XF, Yang G, Mao W, Thornton A, Liu J, Bast RC Jr and Le XF: HER2 signaling modulates the equilibrium between proand antiangiogenic factors via distinct pathways: Implications for HER2-targeted antibody therapy. Oncogene 25: 6986-6996, 2006.

65. Scholl S, Beuzeboc P and Pouillart P: Targeting HER2 in other tumor types. Ann Oncol 12 (Suppl 1): S81-S87, 2001. 
66. Hansel DE, Swain E, Dreicer R and Tubbs RR: HER2 overexpression and amplification in urothelial carcinoma of the bladder is associated with MYC coamplification in a subset of cases. Am J Clin Pathol 130: 274-281, 2008.

67.Eissa S, Ali HS, Al Tonsi AH, Zaglol A and El Ahmady O: HER2/neu expression in bladder cancer: Relationship to cell cycle kinetics. Clin Biochem 38: 142-148, 2005.

68. Tolmachev V: Imaging of HER-2 overexpression in tumors for guiding therapy. Curr Pharm Des 14: 2999-3019, 2008.

69. Slamon DJ, Clark GM, Wong SG, Levin WJ, Ullrich A and McGuire WL: Human breast cancer: Correlation of relapse and survival with amplification of the HER-2/neu oncogene. Science 235: 177-182, 1987.

70. Gandour-Edwards R, Lara PN Jr, Folkins AK, LaSalle JM, Beckett L, Li Y, Meyers FJ and DeVere-White R: Does HER2/neu expression provide prognostic information in patients with advanced urothelial carcinoma? Cancer 95: 1009-1015, 2002.

71. Tinoco G, Warsch S, Glück S, Avancha K and Montero AJ: Treating breast cancer in the 21st century: Emerging biological therapies. J Cancer 4: 117-132, 2013.

72.Slamon DJ, Leyland-Jones B, Shak S, Fuchs H, Paton V, Bajamonde A, Fleming T, Eiermann W, Wolter J, Pegram $\mathrm{M}$, et al: Use of chemotherapy plus a monoclonal antibody against HER 2 for metastatic breast cancer that overexpresses HER2. N Engl J Med 344: 783-792, 2001

73. Smyth EC and Cunningham D: Targeted therapy for gastric cancer. Curr Treat Options Oncol 13: 377-389, 2012.

74. Bang YJ, Van Cutsem E, Feyereislova A, Chung HC, Shen L, Sawaki A, Lordick F, Ohtsu A, Omuro Y, Satoh T, et al: ToGA Trial Investigators: Trastuzumab in combination with chemotherapy versus chemotherapy alone for treatment of HER2-positive gastric or gastro-oesophageal junction cancer (ToGA): a phase 3 open-label randomised controlled trial. Lancet 376: 687-697, 2010.

75. Laé M, Couturier J, Oudard S, Radvanyi F, Beuzeboc P and Vieillefond A: Assessing HER2 gene amplification as a potential target for therapy in invasive urothelial bladder cancer with a standardized methodology: Results in 1005 patients. Ann Oncol 21: 815-819, 2010

76. Underwood M, Bartlett J, Reeves J, Gardiner DS, Scott R and Cooke T: C-erbB-2 gene amplification: A molecular marker in recurrent bladder tumors? Cancer Res 55: 2422-2430, 1995.

77. Schraml P, Kononen J, Bubendorf L, Moch H, Bissig H, Nocito A, Mihatsch MJ, Kallioniemi OP and Sauter G: Tissue microarrays for gene amplification surveys in many different tumor types. Clin Cancer Res 5: 1966-1975, 1999.

78. Latif Z, Watters AD, Dunn I, Grigor K, Underwood MA and Bartlett JM: HER2/neu gene amplification and protein overexpression in G3 pT2 transitional cell carcinoma of the bladder: A role for anti-HER2 therapy? Eur J Cancer 40: 56-63, 2004

79. Ehsani L and Osunkoya AO: Human epidermal growth factor receptor 2 expression in urothelial carcinoma of the renal pelvis: Correlation with clinicopathologic parameters. Int J Clin Exp Pathol 7: 2544-2550, 2014

80. Hussain MH, MacVicar GR, Petrylak DP, Dunn RL, Vaishampayan U, Lara PN Jr, Chatta GS, Nanus DM, Glode LM, Trump DL, et al; National Cancer Institute: Trastuzumab, paclitaxel, carboplatin, and gemcitabine in advanced human epidermal growth factor receptor-2/neu-positive urothelial carcinoma: Results of a multicenter phase II National Cancer Institute trial. J Clin Oncol 25: 2218-2224, 2007.

81. Caner V, Turk NS, Duzcan F, Tufan NL, Kelten EC, Zencir S, Dodurga Y, Bagci $\mathrm{H}$ and Duzcan SE: No strong association between HER-2/neu protein overexpression and gene amplification in high-grade invasive urothelial carcinomas. Pathol Oncol Res 14: 261-266, 2008.

82. Simonetti S, Russo R, Ciancia G, Altieri V, De Rosa G and Insabato L: Role of polysomy 17 in transitional cell carcinoma of the bladder: Immunohistochemical study of HER 2/neu expression and fish analysis of c-erbB-2 gene and chromosome 17. Int J Surg Pathol 17: 198-205, 2009.

83. Li B, Kanamaru H, Noriki S, Fukuda M and Okada K: Numeric aberration of chromosome 17 is strongly correlated with p53 overexpression, tumor proliferation and histopathology in human bladder cancer. Int J Urol 5: 317-323, 1998.

84. Inoue T, Sato K, Tsuchiya N, Matsuura S, Iinuma M, Habuchi $\mathrm{T}$ and Kato T: Numeric aberrations of HER-2 and chromosome 17 detected by fluorescence in situ hybridization in urine-exfoliated cells from patients with urothelial carcinoma. Urology 64 617-621, 2004.
85. Skagias L, Politi E, Karameris A, Sambaziotis D, Archondakis A Vasou O, Ntinis A, Michalopoulou F, Moreas I, Koutselini H, et al: Prognostic impact of HER2/neu protein in urothelial bladder cancer. Survival analysis of 80 cases and an overview of almost 20 years' research. J BUON 14: 457-462, 2009.

86. Sato K, Moriyama M, Mori S, Saito M, Watanuki T, Terada K, Okuhara E, Akiyama T, Toyoshima K, Yamamoto T, et al: An immunohistologic evaluation of C-erbB-2 gene product in patients with urinary bladder carcinoma. Cancer 70: 2493-2498, 1992.

87. Jimenez RE, Hussain M, Bianco FJ Jr, Vaishampayan U, Tabazcka P, Sakr WA, Pontes JE, Wood DP Jr and Grignon DJ: Her-2/neu overexpression in muscle-invasive urothelial carcinoma of the bladder: Prognostic significance and comparative analysis in primary and metastatic tumors. Clin Cancer Res 7: 2440-2447, 2001.

88. Bolenz C, Shariat SF, Karakiewicz PI, Ashfaq R, Ho R, Sagalowsky AI and Lotan Y: Human epidermal growth factor receptor 2 expression status provides independent prognostic information in patients with urothelial carcinoma of the urinary bladder. BJU Int 106: 1216-1222, 2010

89. Naruse K, Yamada Y, Nakamura K, Aoki S, Taki T, Zennami K, Katsuda R, Watanabe M, Nishikawa G, Itoh Y, et al: Potential of molecular targeted therapy of HER-2 and Cox-2 for invasive transitional cell carcinoma of the urinary bladder. Oncol Rep 23: 1577-1583, 2010.

90. Charfi S, Khabir A, Mnif H, Ellouze S, Nabil Mhiri M and Boudawara-Sellami T: Immunohistochemical expression of HER2 in urothelial bladder carcinoma and its correlation with p53 and p63 expression. J Microsc Ultrastruct 1: 17-21, 2013

91. Krüger S, Weitsch G, Büttner H, Matthiensen A, Böhmer T, Marquardt T, Sayk F, Feller AC and Böhle A: HER2 overexpression in muscle-invasive urothelial carcinoma of the bladder: Prognostic implications. Int J Cancer 102: 514-518, 2002.

92. Li J, Jackson CL, Yang D, Noble L, Wheeler M, MacKenzie $\mathrm{D}$, Adegun T and Amin A: Comparison of tyrosine kinase receptors HER2, EGFR, and VEGFR expression in micropapillary urothelial carcinoma with invasive urothelial carcinoma. Target Oncol 10: 355-363, 2015

93. Kim B, Kim G, Song B, Lee C, Park JH and Moon KC: HER2 protein over- expression and gene amplification in plasmacytoid urothelial carcinoma of the urinary bladder. Dis Markers 6: 2016, 2016

94. Miyama Y, Morikawa T, Nakagawa T, Homma Y and Fukayama M: Lipid cell and micropapillary variants of urothelial carcinoma of the ureter. Case Rep Oncol 8: 515-519, 2015.

95. Sauter G, Moch H, Moore D, Carroll P, Kerschmann R, Chew K, Mihatsch MJ, Gudat F and Waldman F: Heterogeneity of erbB-2 gene amplification in bladder cancer. Cancer Res 53: 2199-2203, 1993.

96. Coogan CL, Estrada CR, Kapur S and Bloom KJ: HER-2/neu protein overexpression and gene amplification in human transitional cell carcinoma of the bladder. Urology 63: 786-790, 2004

97. Behzatoğlu K, Yörükoğlu K, Demir H and Bal N: Human epidermal growth factor receptor 2 overexpression in micropapillary and other variants of urothelial carcinoma. Eur Urol Focus: Jun 21, 2016 (Epub ahead of print).

98. Makise N, Morikawa T, Takeshima Y, Fujimura T, Homma Y and Fukayama M: Urinary bladder urothelial carcinoma with concurrent plasmacytoid and micropapillary differentiations: A report of two cases with an emphasis on serum carbohydrate antigen 19-9. Pathol Int 65: 495-500, 2015

99. Goodman AL and Osunkoya AO: Human epidermal growth factor receptor 2 expression in micropapillary urothelial carcinoma of the bladder: An analysis of 27 cases. Hum Pathol 57: 160-164, 2016

100.El Ochi MR, Oukabli M, Bouaiti E, Chahdi H, Boudhas A, Allaoui M, Ameur A, Abbar M and Al Bouzidi A: Expression of human epidermal growth factor receptor 2 in bladder urothelial carcinoma. BMC Clin Pathol 17: 3, 2017.

101. Kriegmair MC, Wirtz RM, Worst TS, Breyer J, Ritter M, Keck B Boehmer C, Otto W, Eckstein M, Weis CA, et al: Prognostic value of molecular breast cancer subtypes based on Her2, ESR1, PGR and Ki67 mRNA-expression in muscle invasive bladder cancer. Transl Oncol 11: 467-476, 2018.

102. Wolff AC, Hammond MEH, Allison KH, Harvey BE, Mangu PB, Bartlett JMS, Bilous M, Ellis IO, Fitzgibbons P, Hanna W, et al: Human epidermal growth factor receptor 2 testing in breast cancer: American Society of Clinical Oncology/College of American Pathologists clinical practice guideline focused update. J Clin Oncol 36: 2105-2122, 2018. 
103. Latif Z, Watters AD, Dunn I, Grigor KM, Underwood MA and Bartlett JM: HER2/neu overexpression in the development of muscle-invasive transitional cell carcinoma of the bladder. Br J Cancer 89: 1305-1309, 2003.

104. Hynes NE and Stern DF: The biology of erbB-2/neu/HER-2 and its role in cancer. Biochim Biophys Acta 1198: 165-184, 1994.

105. Knowles MA and Hurst CD: Molecular biology of bladder cancer: New insights into pathogenesis and clinical diversity. Nat Rev Cancer 15: 25-41, 2015.

106. Ross JS, Wang K, Khaira D, Ali SM, Fisher HA, Mian B, Nazeer T, Elvin JA, Palma N, Yelensky R, et al: Comprehensive genomic profiling of 295 cases of clinically advanced urothelial carcinoma of the urinary bladder reveals a high frequency of clinically relevant genomic alterations. Cancer 122: 702-711, 2016.
107. Wülfing C, Machiels JP, Richel DJ, Grimm MO, Treiber U, De Groot MR, Beuzeboc P, Parikh R, Pétavy F and El-Hariry IA: A single-arm, multicenter, open-label phase 2 study of lapatinib as the second-line treatment of patients with locally advanced or metastatic transitional cell carcinoma. Cancer 115: 2881-2890, 2009.

108. Mercogliano MF, Inurrigarro G, De Martino M, Venturutti L, Rivas MA, Cordo-Russo R, Proietti CJ, Fernández EA, Frahm I, Barchuk S, et al: Invasive micropapillary carcinoma of the breast overexpresses MUC4 and is associated with poor outcome to adjuvant trastuzumab in HER2-positive breast cancer. BMC Cancer 17: 895, 2017. International (CC BY-NC-ND 4.0) License. 